MATEC Web of Conferences 47, 03010 (2016)

DOI: $10.1051 /$ matecconf $/ 20164703010$

(C) Owned by the authors, published by EDP Sciences, 2016

\title{
Assessment of Road Infrastructures Pertaining to Malaysian Experience
}

\author{
Norshakina Samsuddin ${ }^{1, a}$ and Mohd Idrus Mohd Masirin ${ }^{1}$ \\ ${ }^{1}$ Faculty of Civil and Environmental Engineering, Universiti Tun Hussein Onn Malaysia, 86400 Parit Raja, Johor, \\ Malaysia
}

\begin{abstract}
Road Infrastructures contribute towards many severe accidents and it needs supervision as to improve road safety levels. The numbers of fatalities have increased annually and road authority should seriously consider conducting programs or activities to periodically monitor, restore of improve road infrastructure. Implementation of road safety audits may reduce fatalities among road users and maintain road safety at acceptable standards. This paper is aimed to discuss the aspects of road infrastructure in Malaysia. The research signifies the impact of road hazards during the observations and the impact of road infrastructure types on road accidents. The F050 (Jalan Kluang-Batu Pahat) road case study showed that infrastructure risk is closely related with number of accident. As the infrastructure risk increase, the number of road accidents also increase. It was also found that different road zones along Jalan KluangBatu Pahat showed different level of intersection volume due to number of road intersection. Thus, it is hoped that by implementing continuous assessment on road infrastructures, it might be able to reduce road accidents and fatalities among drives and the community.
\end{abstract}

\section{Introduction}

Road infrastructure is the main element in road transport system in developing country like as Malaysia. It can be defined as the basic facilities, services and installation needed for the functioning of transport highway, roads and streets [7,8]. Implementation of road specific infrastructure can help to reduce road accident and improve the road safety level in all stage. In the world stage, about 1.3 million people die and as many as 50 million are injured or permanently disabled in road crashes [1]. The report has highlighted that almost half of those who die in road traffic crashes are pedestrian, cyclist and motorcyclist. It showed the vulnerable road user will offer to higher of casualties. They are generally the outcome of the interaction of many factors in chain in event involving the vehicle and the environment. The factor can be broadly categorized into human factor, road and environment. But, most of crashes are caused by human error but to fix the human mistake it's possible because in psychology finding human always make mistakes [2]. National safety study show investment in safer infrastructure is better to deliver twice the casualty saving provided by investment in either behavior or vehicle. In order to evaluate road infrastructure performance, auditing technique has been performed based on the Road Safety Audits Stage 5. Road infrastructure has been list according to the Guideline of Road Safety Audit Stage 5, Arahan Teknik Jalan (ATJ) and Guidebook for Traffic and

\footnotetext{
${ }^{a}$ Corresponding author : misshakina@gmail.com
} 
Safety Audits in order to offer the safe road to road user. The components of the road infrastructure are road alignment, cross section, intersection (signalised and unsignalised), interchange, bridge, tunnel, vulnerable infrastructure, roadside safety and road surface. Poor design of the road infrastructure can be effect on the safe operation of the road. To fix the impact during the accident, road infrastructure can be used as pre-prevention techniques. Application of Road Safety Audits Stage 5 is a one of the method to ensure safe road infrastructure along the road in Malaysia.

\section{Road Infrastructure Related Risk}

Road infrastructure is one of the main factors determining the level of safety features in road transport system. In United State, road condition offer 53\% factor on road crashes [6]. Poor road infrastructure can influence on the driver's compliance level and it will cause unsafe situation among the driver [9]. Serious consideration in road safety is the influence of the road geometry, roadside installation such as barriers, posts, road marking and etc. Related risk due to the bad infrastructure provided such as poor road side protection, poor road design, poor access management, work/construction zone safety, poor pavement management, poor traffic management and poor road hierarchy discipline or land use issue. Figure 1 shows the example of the infrastructure failure due to the road risk. It was also investigated that road infrastructures such as drains and other furniture may result in accident [3]. Mohd Idrus [4] also reported that undulating road surfaces may also contribute towards serious road accidents as studied in Batu Pahat, Malaysia.

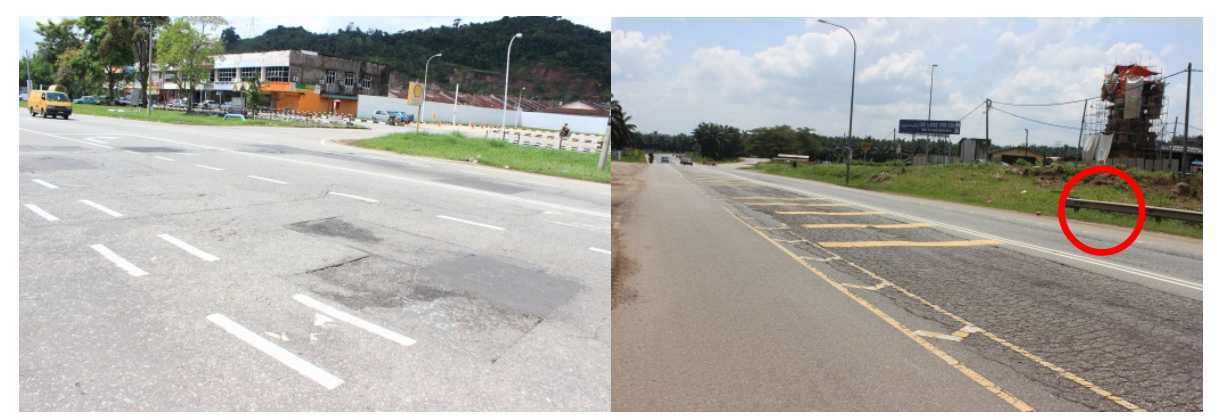

Figure 1. Pavement defect and improper of ending point of barrier in Federal Route F001.

\section{Safe Road Infrastructure}

Safe road infrastructure may involve planning, design, implementation and maintenance in every level of activity. Therefore, proper management are needed to ensure all the element of road infrastructure was built and equipped according to the standard which able to function properly or not. Many lives could be saved and many accidents avoided if the existing road infrastructure was managed according to the best practice of safety engineering. The important to have a proper road infrastructure such as clear signs and road marking is essential if road users are to know what they are expected to do [10].

\section{Applications of Road Safety Audits}

Road safety audits have been declared as a proven method to prevent the road accident. RSA process aimed to identify of potential safety hazards on new road project at the appropriate stage, identify of hazardous features of an existing road so that it can be eliminated or treat before they become accident prone locations. It also to ensure the safety requirement of all road user are be consider in all stage and its aim to reduce the overall "through life" costs of a road project to the community. In Malaysia, they are five stages in RSA application which are: Stage 1 Audit: Feasibility and Planning Stage, Stage 2 
Audit: Draft (Preliminary) Design Stage, Stage 3 Audit: Detailed Design Stage, Stage 4 Audit: The Pre-opening Stage and Stage 5 Audit: RSA of an Existing Road.

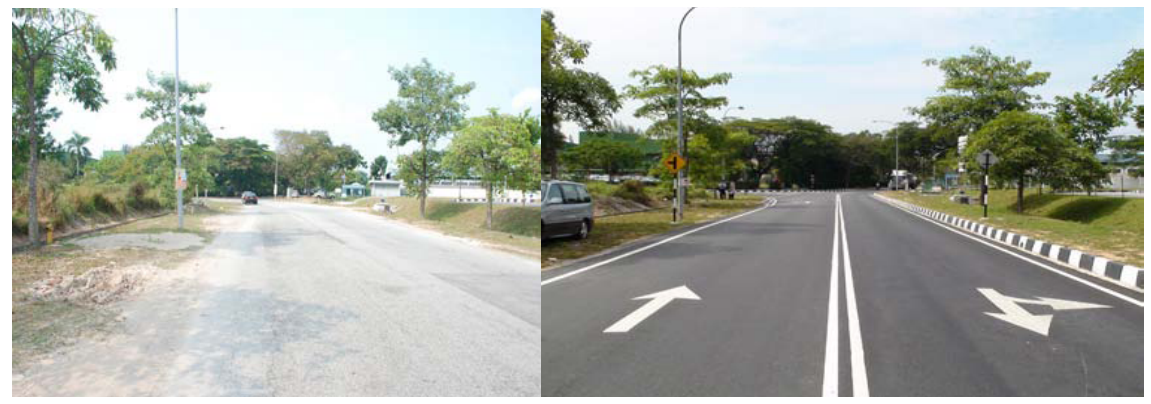

Figure 2. Sight distance and delinetion improvement [10].

\subsection{Road safety audits stage 5}

Application of the RSA in this stage will ensure safer road infrastructure operated on the existing road. It will help to identify safety problem which develop due to normal 'wear and tear' from traffic operation and identify hazards due to the way the landscaping matured such as trees, foliage obstructing traffic signs or distance impaired. Furthermore, at this stage audit will particularly look at the way each road user group 'sees' the road from their particular safety viewpoint. Road design standard made with regard to five main aspects namely functionality, economy, safety, comfort and aesthetic $[8,11]$. The element list in this stage are vertical and horizontal alignment, cross section, intersection, expressway interchange and other grade separated intersections, traffic signal installation, traffic signing, roadside safety and landscaping, pavement marking, street lighting and general traffic management items. But in this study, its only focus on the road infrastructure consist of the road pavement conditions, road marking, cross section, road side safety and landscaping, road signing, street lighting, road barrier, traffic signal installation, road bridge and the number of intersection. All the items selected based on the road safety element that are related to the road environment and basic infrastructure needed along the road.

\section{Method of Data Collection}

Data collection on this study was conducted based on the research method according to the standard guideline on the locations of the studies. There two different data collection method, there are:

a) Road Infrastructure Data: Site observation was implemented to observe the state of weakness and lack of road infrastructure with reference guided manual of Road Safety Audits Stage 5, Arahan Teknik Jalan (ATJ) and Geometric Design Guide Road.The data analysed using HIRARC method where it helped to analyse the factors of the accident on the road based on the audits. The study areas in this stage only focus from KM 10 to KM 24 . The area has been selected based on the data of the accident, zone area, and type of the infrastructure in that area.

b) Intersection Data: Preliminary works was carried in order to select the critical junction along the F050 road. Critical junctions was been selected based on the factor of level of users, location of the junction and strategic factor. Site observation was been conducted at the selected area (traffic volume count, junction audit) based on the JKR standards and RSA guidelines. The study areas only focus from KM 19 to KM 32. This is because the area must full fill the junctions characteristic such as main road of the junctions didn't have the road divider, unsignalised junctions and the junctions had been use for vehicles as the way to entering and exiting the house or the public utilities. 


\section{Results and Discussion}

\subsection{Road infrastructures analysis}

From the data observation, HIRARC analysis was conducted to identify risk at every kilometer and every types of infrastructure. The risk assessed by considering the possibility danger at every type of infrastructure available along the road (KM 10 to KM 24). Figure shows the result of risk and analysis for each kilometer and percentage of risk analysis for each type of road infrastructure involved.

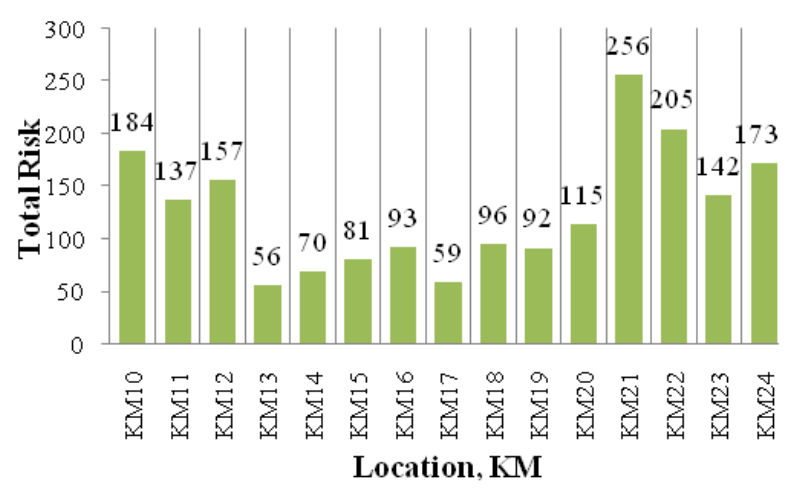

Figure 3. Total Risk based on the location.

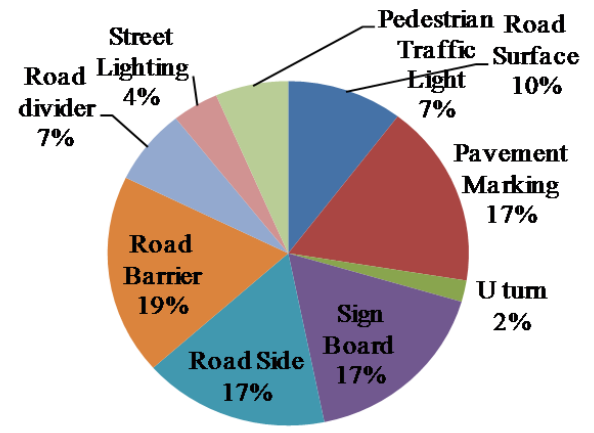

Figure 4. Percentage of Risk based on the types of infrastructure.

\subsection{Road intersection analysis}

From the data observation, critical junctions were selected based on the accident statistic along the F050 from KM 19 to KM 32. There for, 9 critical junctions were selected as follow in Table 1. Zone classifications are based on the number of the accident and number of the intersection in one kilometer area. There for, critical zone have been classified to the three phases, there are Less Critical Zone (119 accident), Semi Critical Zone (20-39 accident) and Critical Zone (40-59 accident). 
Table 1. Critical junction choose and selection factor.

\begin{tabular}{|c|c|c|c|c|c|}
\hline KM & $\begin{array}{c}\text { No. of } \\
\text { Junction }\end{array}$ & $\begin{array}{c}\text { Junction } \\
\text { Name }\end{array}$ & $\begin{array}{c}\text { Junction } \\
\text { Code }\end{array}$ & Selection Factor & $\begin{array}{l}\text { Intersection } \\
\text { Vol. }\end{array}$ \\
\hline $\begin{array}{c}\mathrm{KM} \\
21\end{array}$ & 1 & $\begin{array}{l}\text { Taman } \\
\text { MajuBaru }\end{array}$ & TMB & $\begin{array}{l}\text { - Shop house and residential areas. } \\
\text { - Away from PintasPuding Traffic } \\
\text { Light }\end{array}$ & 2246 \\
\hline \multirow[t]{3}{*}{$\begin{array}{c}\mathrm{KM} \\
22\end{array}$} & \multirow[t]{3}{*}{3} & Taman Senang & $\mathrm{TS}$ & $\begin{array}{ll}\text { - } & \text { Linking many townships } \\
\text { - } & \text { Area near the city } \\
\text { - } & \text { Slopes intersection } \\
\end{array}$ & 2140 \\
\hline & & Jalan Raja 1 & JR1 & $\begin{array}{l}\text { - Intersection of shop house and } \\
\text { housing } \\
\text { - Urban areas and crowded }\end{array}$ & 2354 \\
\hline & & $\begin{array}{l}\text { Taman } \\
\text { BungaCempak } \\
\text { aBaru }\end{array}$ & TBCB & $\begin{array}{l}\text { - Shop houses and residential areas } \\
\text { - Urban areas and crowded }\end{array}$ & 2680 \\
\hline $\begin{array}{l}\text { KM } \\
23\end{array}$ & 1 & Taman Manis 2 & TM2 & $\begin{array}{l}\text { - Shop houses and residential areas } \\
\text { - Linking many residential areas }\end{array}$ & 1917 \\
\hline $\begin{array}{c}\mathrm{KM} \\
24\end{array}$ & 1 & Parit Haji Ali & PHA & - Intersection of big village & 2032 \\
\hline \multirow[t]{2}{*}{$\begin{array}{c}\mathrm{KM} \\
31\end{array}$} & \multirow[t]{2}{*}{2} & Taman UPC & UPC & $\begin{array}{l}\text { - Near the corner of the road } \\
\text { - The area of houses and shop house }\end{array}$ & 1196 \\
\hline & & $\begin{array}{ll}\text { Taman } & \text { Ayer } \\
\text { Hitam } & \\
\end{array}$ & TAH & $\begin{array}{l}\text { - Near town and school } \\
\text { - Slopes intersection }\end{array}$ & 1367 \\
\hline $\begin{array}{c}\mathrm{KM} \\
32\end{array}$ & 1 & $\begin{array}{l}\text { JalanSeroja } \\
\text { (PejabatPos } \\
\text { Air Hitam) }\end{array}$ & JS & $\begin{array}{l}\text { - Urban area and crowded } \\
\text { - Intersection of housing and Post } \\
\text { Office } \\
\text { - Near Traffic Light Ayer Hitam }\end{array}$ & 1736 \\
\hline
\end{tabular}

\subsection{Related risk due to road infrastructure}

Figure 5 shows the correlation between the infrastructure risks against accident. Based on the graph analysis against the accident rate, it can be conclude that the factors of road infrastructure can also cause of the accident.

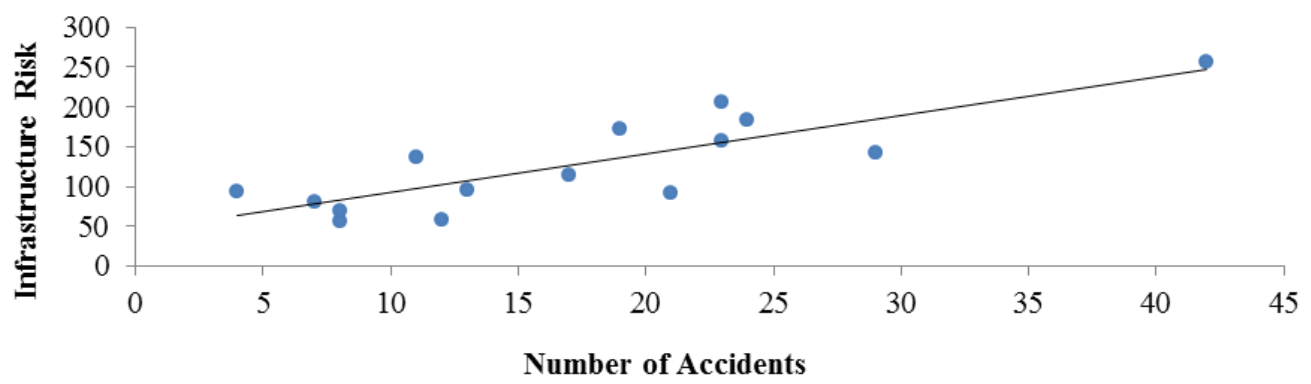

Figure 5. Graph of total infrastructure risk against accidents [4].

\subsection{Related risk due to the access road}

Figure 6 shows the correlation between volume of junction and accident data. Through the analysis it found that critical zone offer less of intersection with the high of accident rate and lowest to moderate of vehicle volume in each junction. It can be conclude that if the intersection has a high volume of vehicle, it was not guaranteed the accident always at high of the intersection. This is, probability of 
accident happen more to the location of the intersection and the layout and design of intersection. The dangerous location lead to serious accident occurs.

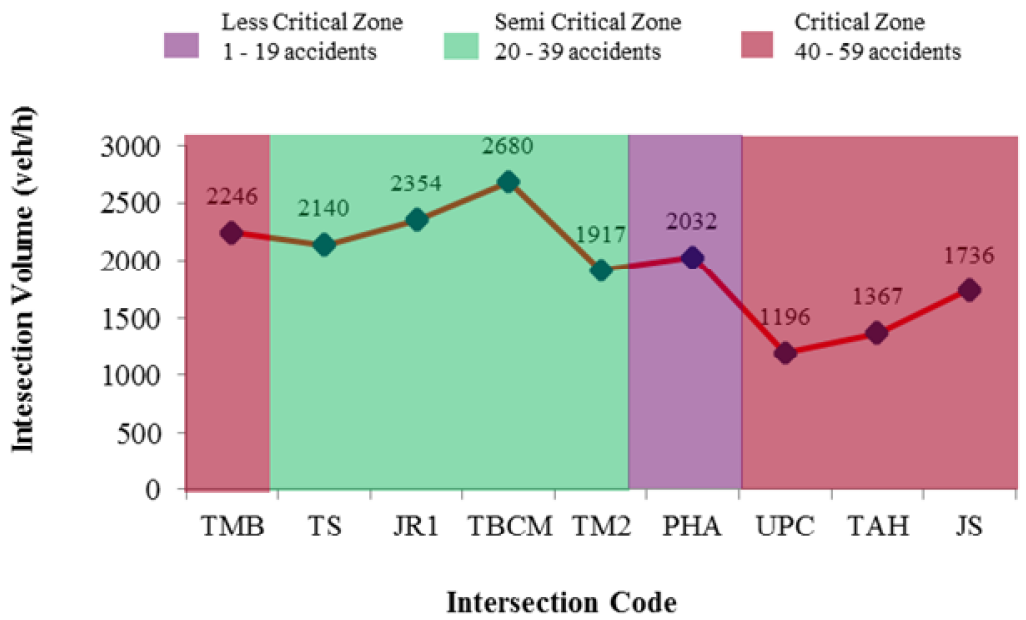

Figure 6. Relationship between the volumes of critical junction with accident zone.

\section{Conclusion}

Road safety infrastructure should be applied in all level of development, in order to maximize the impact due to engineering field and to solve the safety problem among the road user. By applying the good design principle, it will possible to avoid the safety problem occur. Through the implementation of road infrastructure audits and a set of data, we can define the hazard and problem occurs in that area. It will help the policy makers to make a decision considering the safety evaluation in the planning from the beginning as there is often when a need for extrasafety features. Installation of good and complete infrastructure components along the road would reduce the rate of accidents and it can make road user feel more comfortable driving on the roads.

\section{References}

[1] World Health Organization, Global Status Report On Road Safety 2013, Supporting A Decade of Action, Luxembourg, (2013).

[2] International Road Assessment Programme, iRAP Result, Malaysia, (2009).

[3] A.H.M. Nor, M.I.M. Masirin and M.E. Sanik, Site investigation of road drains for rural road on Batu Pahat soft clays (BPSC), J. Mech. and Civil Eng., IOSR, (2014).

[4] M.I.M Masirin, Performance Evaluation of Encapsulated Road Pavement on Different Ground Condition, PhD Thesis, British Library, United Kingdom, (2007).

[5] PDRM, Kemalangan Jalan Raya di Malaysia, Laporan Polis Diraja Malaysia 2013, Kuala Lumpur Malaysia, (2013).

[6] United Nation Road Safety Collaboration, A Policy Framework for Safe Infrastructure on Major Road Transport Networks, FIA Foundation Report, <available online http://www.irfnet.ch /filesupload/pdf.files/UNRSC\%20Infrastructure\%20Document\%201r\%20Final.pdf $>$

[7] Inland Transportation Service, Road Infrastructure Safety Management on the Trans-European Networks, Consultation Paper TREN E3, European Commission, Brussels, (2006).

[8] M.I.M. Masirin, analysis of road infrastructural audit (RIS) along Jalan BatuPahat-Kluang Malaysia: A case study, Proceeding of International Integrated Engineering Seminar, Batu Pahat, (2014). 


\section{IConCEES 2015}

[9] D. Friday, Modification of road infrastructure to increase driver compliance in Uganda, International Journal of Advances in Management and Economics, 1(3), 78-87, (2012).

[10]R.N. Zaman, Road Safety Audit Report MRSA 01/2012, Malaysian Institute of Road Safety Research, (2012).

[11]M. Sanusi, Audit Keselamatan Jalan Raya Dalam Kampus Universiti Teknologi Malaysia, Dissertation, Universiti Teknologi Malaysia, Skudai, (2006).

[12]Public Work Department, Arahan Teknik Jalan, Kuala Lumpur, (2006). 